\title{
Evaluation of Factors in Buying Decision Process of Furnifure Consumers by Applying AHP Method
}

\section{Vrednovanje činitelja u procesu donošenja odluke o kupnji namještaja primjenom AHP metode}

Original scientific paper • Izvorni znanstveni rad

Received-prispjelo: 18. 4. 2016.

Accepted-prihvaćeno: 15. 11. 2016.

UDK: $630 * 79$

doi:10.5552/drind.2017.1625

\begin{abstract}
There are not many wooden products that consumers would buy on pure impulse. Their decision regarding the purchase of a product normally undergoes a process of consideration - the more expensive the product, the more thorough the consideration. The consumer buying decision process consists of five stages: need recognition, search for information, alternatives evaluation, purchase decision and post-purchase behaviour. A company must establish what is important for consumers in each stage of this process. On the basis of these findings, the company must define the measures to influence consumers in individual phases. In this study, the analytic hierarchy process was used to analyse the buying behaviour of potential furniture buyers. Slovenian and Croatian marketing experts were asked about the habits, requests and needs of furniture buyers. The results of the research can serve as useful information for companies producing wooden products in the formulation of successful marketing strategies.
\end{abstract}

Key words: buyer decision process, buying behaviour, wood company, furniture, AHP

SAŽETAK - Ne postoji mnogo proizvoda od drva koje bi kupci kupili impulzivno, bez dodatnog poticaja $i$ razmišljanja. Odluka potencijalnog kupca s obzirom na vrstu proizvoda obično prolazi kroz proces razmatranja, i to na način da je za skuplji proizvod razmatranje detaljnije. Proces donošenja odluke o kupnji nekog proizvoda ima pet faza: prepoznavanje potrebe, potraga za informacijom, vrednovanje alternativa, odluka o kupnji i ponašanje nakon kupnje. Tvrtka mora utvrditi što je njezinim potencijalnim kupcima (potrošačima) u svakoj fazi procesa donošenja odluke o kupnji važno. Na temelju toga, tvrtka mora odrediti mjere kojima će utjecati na potrošača u pojedinim fazama procesa razmatranja. Cilj ovog rada bio je vrednovati činitelje u procesu donošenja odluke o kupnji namještaja primjenom metode analitičkoga hijerarhijskog procesa (AHP). Vrednovanje pokazatelja navika, zahtjeva i potreba kupaca namještaja proveli su suradnici iz Slovenije i Hrvatske koji se bave istraživanjima i aktivnostima u području marketinga. Rezultati istraživanja mogu pomoći proizvođačima i/ili prodavačima namještaja u procesima definiranja uspješnih marketinških strategija.

Ključne riječi: proces donošenja odluke, ponašanje pri kupnji, tvrtke drvne industrije, namještaj, AHP

\footnotetext{
${ }^{1}$ Authors are associate professors at Biotechnical Faculty, University of Ljubljana, Slovenia. ${ }^{2}$ Authors are assistants at Faculty of Forestry, University of Zagreb, Croatia. ${ }^{3}$ Author is assistant professor at Biotechnical Faculty, University of Ljubljana, Slovenia.

Autori su izvanredni profesori na Biotehničkom fakultetu Sveučilišta u Ljubljani, Slovenija. ${ }^{2}$ Autorice su asistentice na Šumarskom fakultetu Sveučilišta u Zagrebu, Hrvatska. ${ }^{3}$ Autorica je docentica na Biotehničkom fakultetu Sveučilišta u Ljubljani, Slovenija.
} 


\section{INTRODUCTION}

\section{UVOD}

In a constantly changing environment, understanding the buying behaviour of consumers is of key importance for a company, if the company wishes to be efficient and successful. Furniture is a type of product that consumers select with a great deal of consideration and spend a lot of time before they finally decide to buy it

\section{CONSUMER BUYING DECISSION PROCESS}

\section{PROCES DONOŠENJA ODLUKE O KUPNJI}

If companies want to be successful in the domain of sales, they must be familiar with the consumer's needs, and their perception and behaviour in the buying decision process. Companies must examine and understand the buying decisions of consumers.

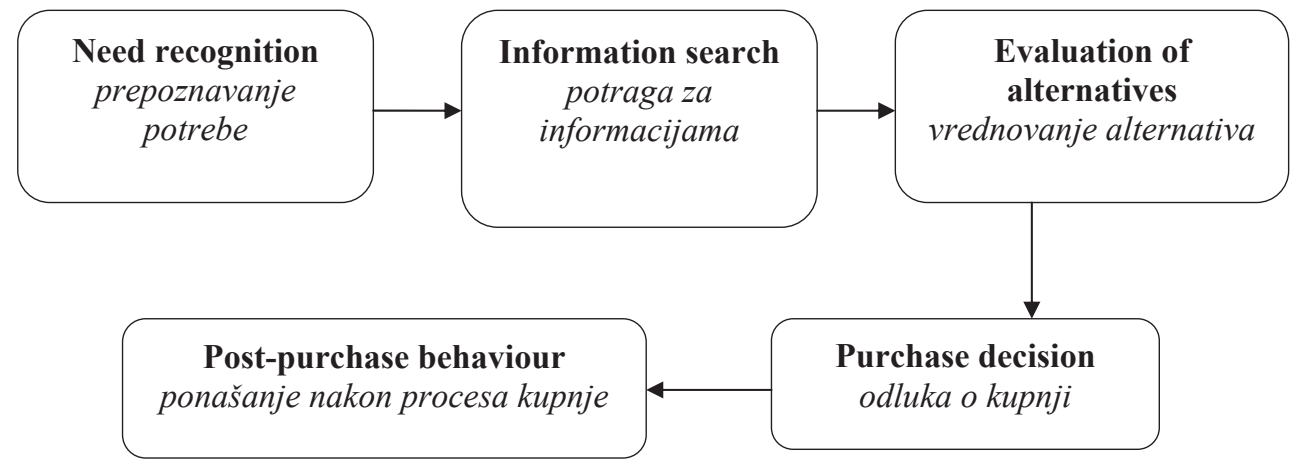

Figure 1 Consumer buying decision process

Slika 1. Proces donošenja odluke o kupnji

(Oblak, 2012). The consumer buying decision process consists of five stages: need recognition, search for information, evaluation of alternatives, purchase decision, and post-purchase behaviour. The actual purchase is, therefore, only one stage in the buying decision process. The initial stages are essential in order to make a purchase; however, the consumer may stop the buying decision process at any point (Potočnik, 2002). This process is influenced by numerous factors. A company's marketing activities are an important factor. In order to prepare appropriate marketing strategies, the company must first identify and understand how consumers think in the individual stages of the buying decision process. It is, therefore, reasonable to analyse the influences on the purchasing behaviour of potential customers. Marketing professionals must understand the consumer's perception, which is not a simple task since consumers often make unexpected buying decisions. Marketing professionals must not just come up with simple ways to influence consumers, but must instead learn how the consumers really make their buying decisions (Kotler, 1994).

The objective of this article was to determine which stages within the buying process are the most important for marketing professionals; what encourages the need recognition in potential furniture buyers; where do they look for information on furniture; which criteria are the most important in the buying decision and which household member is the one that decides on the purchase in most cases. An additional objective was to determine if there were any differences between the Slovenian and Croatian markets, and what were the key differences between the buying decision process of Slovenian and Croatian furniture buyers. The results of the study should be interesting for manufacturers and sellers of furniture in Slovenia and Croatia as well as for all furniture manufacturers that sell their products on these two target markets.
The buying decision process starts when the consumer recognizes a need or desire for a certain product. This is the first and determining stage in the consumer buying decision process. The company can and must actively participate in this process. First of all, it should be established whether the inactivity of buyers and their lack of interest in the company's products is a consequence of the absence of a need for these products or that they do have a need but are still not interested in making a purchase. In both cases, the company can trigger this stage through their activities. In the first case, they must prepare marketing strategies that create the need, and in the second case, they must prepare strategies that will encourage consumers to buy products that meet their need. In doing this, the marketing activities must draw the attention of consumers to the existing products that were unknown to them. There are many potential furniture buyers who are currently not considering a purchase, but the company could convince them to buy their products anyway with correctly prepared components of the marketing communications mix. Consumers who are already considering making a purchase but are not sure yet are even easier to convince. Also, there are always some consumers that are interested in buying a product even if they do not actually need it. It is a known fact that successful advertising and other marketing activities can convince certain consumers to buy furniture even if they do not need it.

The second step in the consumer buying decision process is the information search. When consumers feel the need for a particular product, they will search for information on various alternatives or variants. This information is usually related to price, quality, characteristics and the availability or delivery date of the product. The information on warranty, servicing, after-sales services, payment terms, etc. is also relevant. At this stage, the company can actively partici- 
pate and submit product information to the consumer in a useful, accurate and easily understandable form. Consumers will first seek information from their relatives, friends and acquaintances. According to the studies performed, this information has a huge influence on the buying decision. The media are the second most important source of information (television, radio, the internet, journals, newspapers, etc.). The company's sales staff can play a decisive role in this phase of the buying decision process.

When the consumer has collected enough information, he/she enters the third stage of the buying decision process, in which he/she selects the products that could meet his/her need. The consumer will try to select the most suitable product from among these products or among alternative furniture suppliers. To that end, he/she will form the criteria according to which he/she compares the characteristics of each product. Some of these criteria are more important and have a greater value for the consumer. Usually the price and quality are the most important, while other criteria can also be decisive for some consumers (e.g. brand). In evaluating the alternatives, the sales staff can also play a very important role. Consumers have often not made up their mind and a good salesperson can use professional arguments to convince an indecisive consumer to buy a certain product.

Purchase is the fourth stage in which the consumer decides to buy the product. In some cases, negotiations on the sales conditions between the consumer and the salesperson take place at this stage, mostly regarding the price, terms of payment, warranty, delivery period, etc. If the purchase conditions are acceptable for the buyer, the actual purchase will take place. It is also interesting for companies to know which member of the household makes the decision on the purchase of furniture. This aspect is mostly important in terms of marketing communication.

When a consumer buys a product, he/she will start to evaluate it. This is the last, fifth stage in the consumer buying decision process. He/she compares the expectations and the actual effect of the product. The result of this is either satisfaction or dissatisfaction. The consumer's future buying decisions depend on this result. If the consumer is pleased with the product, he/she will continue to buy this company's products and also tell his/her friends and acquaintances about it. In the opposite case, he/she will also tell the others about his/her problems and bad choice of purchase.

\section{MATERIAL AND METHODS 3. MATERIJAL I METODE}

Based on the research objectives, a questionnaire was developed. The questionnaire was segmented into four sections in order to analyse the following questions: 1. What encourages the need recognition in potential furniture buyers?

2. Where do potential buyers search for information about furniture?

3. What are the most important criteria in deciding on the purchase of furniture?

4. Who makes the decision to purchase the furniture? Five marketing experts from Slovenia and five marketing experts from Croatia were selected to participate in this study. The marketing experts were em-

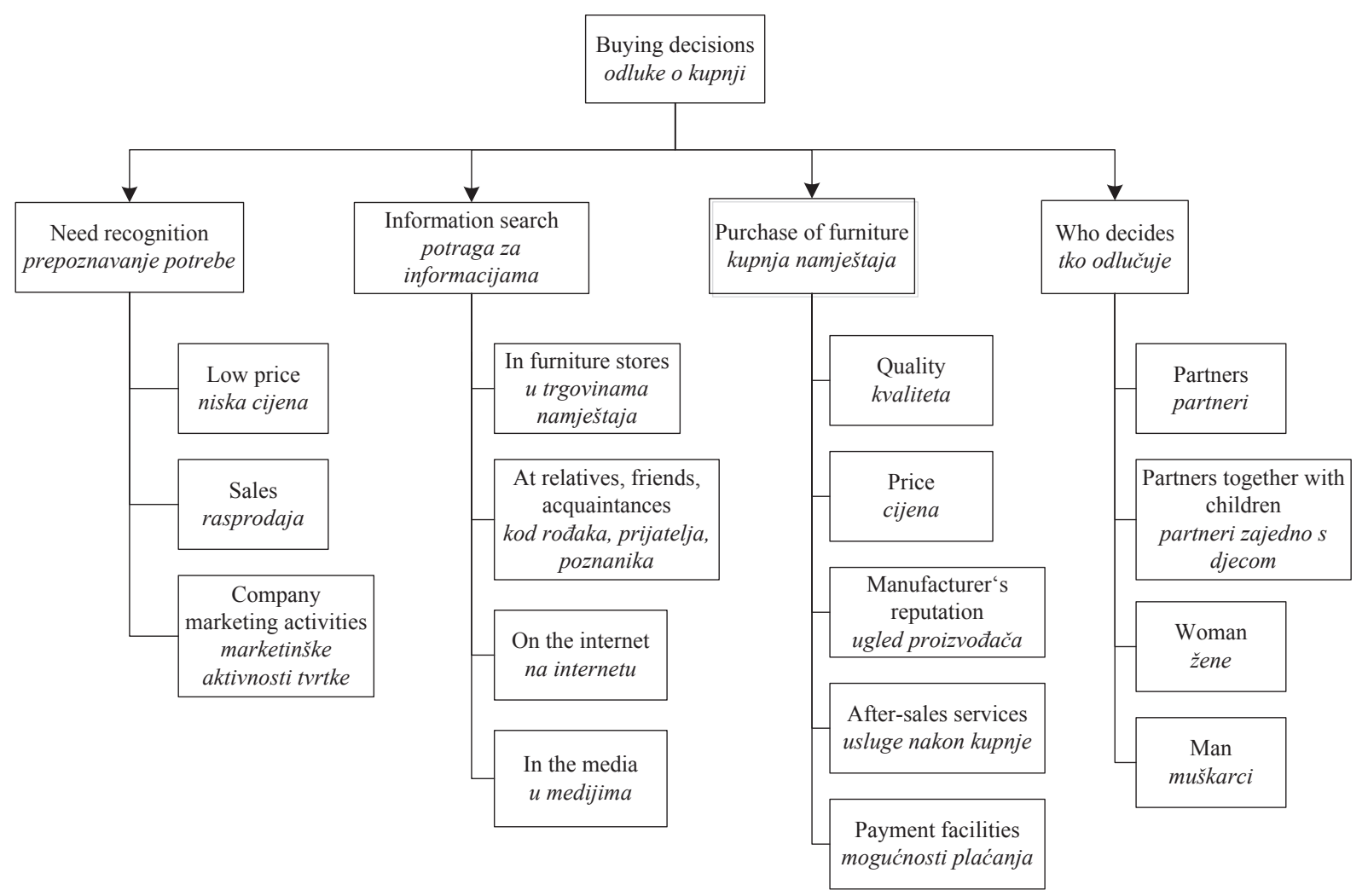

Figure 2 Factors affecting the consumer in the first four stages of the buying decision process Slika 2. Činitelji koji utječu na kupca u prve četiri faze procesa donošenja odluke o kupnji 
ployed to make pairwise comparisons of the factors in each stage regarding buying decision factors (shown in Figure 2). The Analytic Hierarchy Process (AHP) was the method used to analyse data in this study.

\subsection{Analytic hierarchy process}

3.1. Analitički hijerarhijski proces

Analytic Hierarchy Process (AHP) (Saaty, 1980) is a management approach to support multi-criteria decision making in complex real world problems. It has been used in numerous applications in various areas related to wood, furniture, sale and customers. Scholz and Decker (2007) measured the impact of wood species on consumer preferences for wooden furniture. Ojurović et al. (2013) performed analysis of the key factors of competitiveness in wood processing and furniture production. Motik et al. (2010) compared product lines in furniture industry regarding financial efficiency, risk and competition. Esmaili and Fazeli (2015) analysed criteria that influence the purchasing decision of a green product and compared indicators of green products and green promotions activities.

AHP supports rational decision making based on hierarchically structured problems. Pairwise comparisons represent the key phase in AHP. They enable decision maker to express his opinion and preferences about qualitative and quantitative factors. The relative importance of one factor over the other is measured on Saaty's 1-9 scale (Saaty, 2006) (Table 1).

AHP is also suitable for group decision making. The properly chosen decision makers with supplement knowledge, competences and experiences enable success of decision making process. There are different ways to form a group decision from individual decisions (Alonso et al., 2010; Altuzarra et al., 2007; Forman and Peniwati, 1998; Grošelj et al., 2015; Srdjevic and Srdjevic, 2013). In this paper weighted geometric mean DEA (WGMDEA) method (Grošelj et al., 2011) (1) is used to aggregate individual judgments into group vector of weights. The method is based on linear programming and data envelopment analysis and has been employed in several applications (Olšiakova et al., 2016; Stasiak Betlejewska, 2015; Loučanova et al., 2014).

Table 1 Fundamental scale of AHP (Saaty, 2006)

Tablica 1. Temeljna ljestvica AHP-a

\begin{tabular}{|c|c|}
\hline $\begin{array}{l}\text { Value } \boldsymbol{a}_{\mathrm{ij}} \\
\text { Vrijednost }\end{array}$ & Description / Opis \\
\hline 1 & $\begin{array}{l}\text { Elements } i \text { and } j \text { are equally important } \\
\text { elementi }, i " i, j \text { " podjednako su važni }\end{array}$ \\
\hline 3 & $\begin{array}{l}\text { Element } i \text { is slightly more important than } \\
\text { element } j \text { / element , } i \text { “"umjereno je važniji od } \\
\text { elementa , } j \text { " }\end{array}$ \\
\hline 5 & $\begin{array}{l}\text { Element } i \text { is much more important than } \\
\text { element } j \text { / element , } i \text { “mnogo je važniji od } \\
\text { elementa , } j \text { “" }\end{array}$ \\
\hline 7 & $\begin{array}{l}\text { Element } i \text { is proved to be more important than } \\
\text { element } j \text { / element , , } i \text { "izrazito je važniji od } \\
\text { elementa , } j "\end{array}$ \\
\hline 9 & $\begin{array}{l}\text { Element } i \text { is absolutely more important than } \\
\text { element } j \text { / element , , } i \text { "presudno je važniji od } \\
\text { elementa , } j \text { " }\end{array}$ \\
\hline $2,4,6,8$ & Middle values/ međuvrijednosti \\
\hline
\end{tabular}

Individual pairwise comparisons of $m$ decision makers and their reciprocal values for the inverse comparisons are presented in the pairwise comparison matrices, $A_{k}=\left(a_{i j}^{(k)}\right)_{n \times n}, k=1, \ldots, m$.

The consistency of judgments is measured by the consistency ratio $C R_{A}=C I_{A} / R I_{n}$, where consistency index $C I_{A}=\frac{\lambda_{A, \max }-n}{n-1}$ depends on the principal eigenvalue of matrix $A, \lambda_{A, \max }$, and the random index $R I_{n}$ (Saaty, 2006), which depends on the size of the matrix $A$. $C R_{A}<0.1$ is considered acceptably consistent.

Group vector of weights $w=\left(w_{1}, \ldots, w_{n}\right)$ is derived from individual comparison matrices $A_{k}$ by solving $n$ linear programs and then normalizing the weights.

$$
\begin{aligned}
& \max \quad w_{0}=\sum_{j=1}^{n} \sqrt[m]{\prod_{k=1}^{m}\left(a_{0 j}{ }^{(k)}\right)} x_{j} \\
& \text { subject to } \sum_{j=1}^{n}\left(\sum_{i=1}^{n} \sqrt[m]{\prod_{k=1}^{m}\left(a_{i j}{ }^{(k)}\right)}\right) x_{j}=1 \\
& \sum_{j=1}^{n} \sqrt[m]{\prod_{k=1}^{m}\left(a_{i j}{ }^{(k)}\right)} x_{j} \geq n x_{i}, i=1, \ldots, n \\
& x_{j} \geq 0, j=1, \ldots, n \text {. }
\end{aligned}
$$

\section{RESULTS AND DISCUSSION 4. REZULTATI I RASPRAVA}

Results of the AHP method are given in Table 2. Weight vectors are calculated using WGMDEA method separately for Slovenian and Croatian experts, as well as the total weight vectors for both groups. Additionally, the most important factors that influence consumer in the first four stages of the buying decision process were established (Figures 3, 4, 5, and 6).

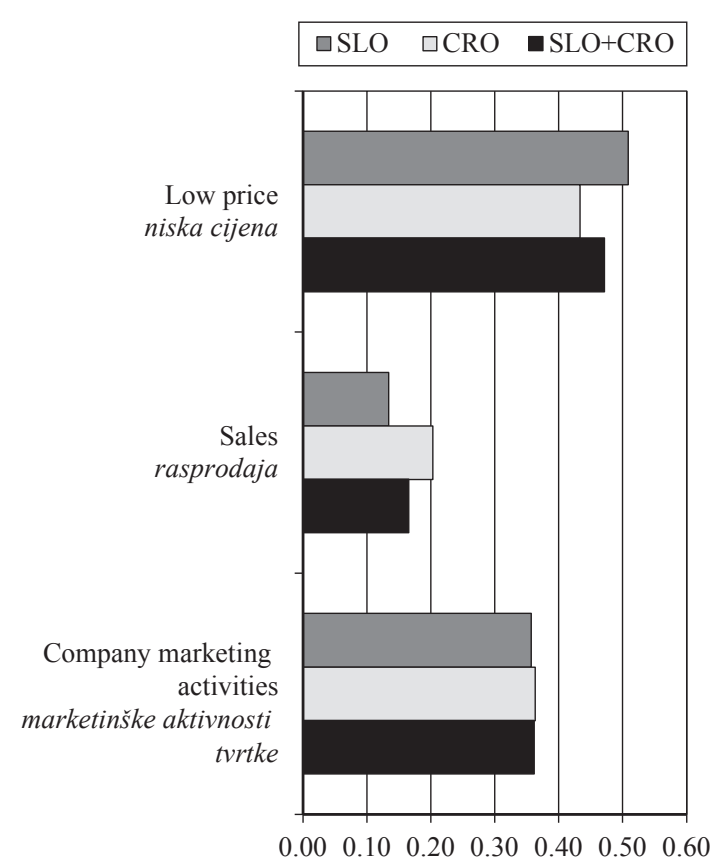

Figure 3 Factors that encourage the need recognition in potential furniture buyers

Slika 3. Činitelji koji potiču na prepoznavanje potrebe potencijalnih kupaca namještaja 
Table 2 Weights of decision making factors for all 4 groups for: a) Slovenian experts (SLO); b) Croatian experts (CRO); and c) Slovenian and Croatian joint results (SLO + CRO)

Tablica 2. Težina/važnost svih četiriju činitelja kupnje prema mišljenju: a) slovenskih stručnjaka (SLO); b) hrvatskih stručnjaka (CRO); c) objedinjeni rezultati slovenskih i hrvatskih stručnjaka (SLO + CRO)

\begin{tabular}{|l|l|c|c|c|}
\hline \multirow{4}{*}{$\begin{array}{l}\text { Need recognition } \\
\text { Prepoznavanje potrebe }\end{array}$} & Sow price / niska cijena & SLO & CRO & SLO+CRO \\
\cline { 2 - 5 } & Sales / rasprodaja & 0.51 & 0.43 & 0.47 \\
\cline { 2 - 5 } & Company marketing activities / marketinške aktivnosti tvrtke & 0.13 & 0.20 & 0.17 \\
\hline \multirow{5}{*}{$\begin{array}{l}\text { Information search } \\
\text { Potraga za informacijama }\end{array}$} & In furniture stores / u trgovinama namještaja & 0.36 & 0.36 & 0.36 \\
\cline { 2 - 5 } & $\begin{array}{l}\text { At relatives, friends, acquaintances } \\
\text { kod rođaka, prijatelja, poznanika }\end{array}$ & 0.27 & 0.24 & 0.26 \\
\cline { 2 - 5 } & On the internet / na internetu & 0.06 & 0.13 & 0.09 \\
\cline { 2 - 5 } & $\begin{array}{l}\text { In the media (TV, radio, printed) } \\
\text { u medijima (na televiziji, radiju, u tiskanim medijima) }\end{array}$ & 0.54 & 0.39 & 0.47 \\
\hline \multirow{5}{*}{$\begin{array}{l}\text { Purchase of furniture } \\
\text { Kupnja namještaja }\end{array}$} & Quality / kvaliteta & 0.13 & 0.25 & 0.18 \\
\cline { 2 - 5 } & Price / cijena & 0.42 & 0.13 & 0.25 \\
\cline { 2 - 5 } & Manufacturer's reputation / ugled proizvođača & 0.28 & 0.46 & 0.38 \\
\cline { 2 - 5 } & $\begin{array}{l}\text { After-sales services (delivery, assembly) } \\
\text { usluge nakon kupnje (dostava, montaža) }\end{array}$ & 0.05 & 0.08 & 0.07 \\
\cline { 2 - 5 } & Payment facilities / mogućnosti plaćanja & 0.14 & 0.10 & 0.13 \\
\hline \multirow{4}{*}{$\begin{array}{l}\text { Who decides } \\
\text { Tko odlučuje }\end{array}$} & Partners / partner & 0.12 & 0.23 & 0.18 \\
\cline { 2 - 5 } & Partners together with children / partner i djeca & 0.41 & 0.24 & 0.32 \\
\cline { 2 - 5 } & Women / žene & 0.13 & 0.12 & 0.13 \\
\cline { 2 - 5 } & Men / muškarci & 0.40 & 0.57 & 0.49 \\
\hline
\end{tabular}

It is evident, as shown in Figure 3, that low price was found to be the major factor of need recognition for buying furniture in Slovenia as well as in Croatia. According the assessment of Slovenian market experts, the weight of this factor was $50.9 \%$, and according to Croatian experts, this weight was $43.4 \%$ (Table 2). The marketing activities of the company got a slightly lower influence on the need recognition in potential furniture buyers (weight of $35.7 \%$ in Slovenia and $36.3 \%$ in Croatia). Sales were the last of the three most important factors that encourage the recognition of a

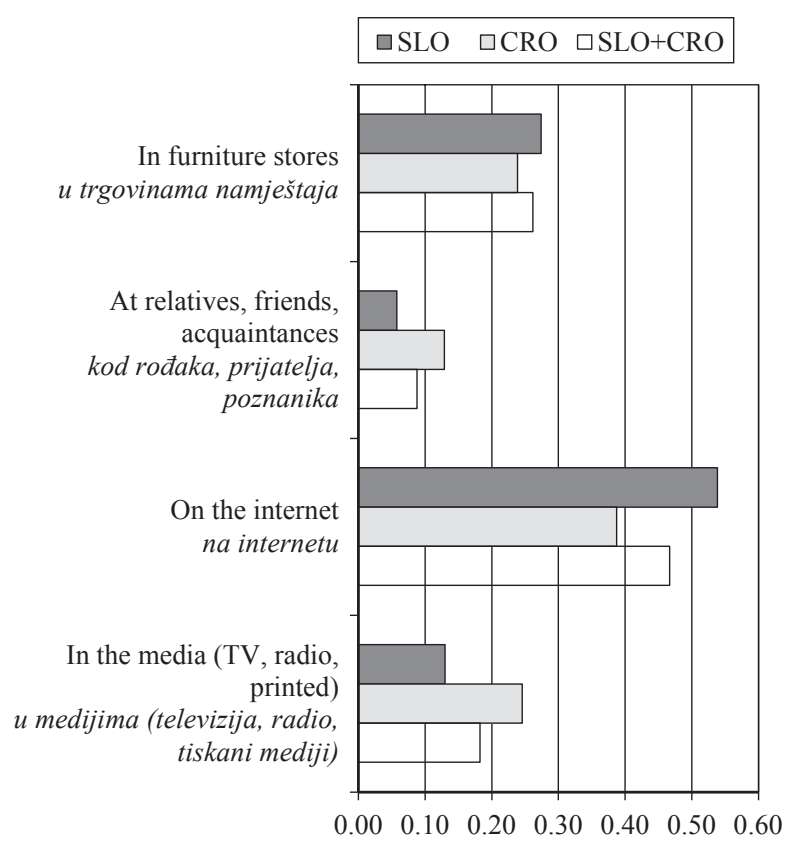

Figure 4 Where do potential buyers search for information about furniture

Slika 4. Mjesta na kojima potencijalni kupci traže informacije o namještaju need for furniture in customers (weight of $13.4 \%$ in Slovenia and $20.3 \%$ in Croatia).

Figure 4 shows where customers, who have identified the need to purchase furniture, seek for information. In both countries, the potential buyers first seek information on the Internet. In Slovenia, this weight was almost twice as high as the next one. The weight of the Internet was $53.8 \%$ and furniture shops, that were the second most important factor, obtained only a weight of $27.4 \%$. The media (TV, radio, printed) was noted as the third most important place where consumers seek information, noting a weight of $13.0 \%$. Consumer's relatives, friends, and acquaintances (with a weight of $5.8 \%$ ) were found to be as the fourth important factor regarding the place where consumers seek information about furniture in Slovenia.

In Croatia, the Internet was established as the most important place for seeking information (weight of $38.7 \%$ ), the media were in the second place (weight of $24.6 \%$ ), furniture shops in the third place with an almost equal weight $(23.8 \%)$ and relatives, friends and acquaintances with a weight of $12.9 \%$ were the fourth most important place where potential buyers sought for information on furniture, but this last weight was more than twice as high as in Slovenia.

With regard to the most important criteria for purchasing furniture, according to the experts' opinion, Slovenian and Croatian consumers vary considerably. In Slovenia, the most important criterion was quality (weight of $41.6 \%$ ) and in Croatia, it was price (weight of $46.0 \%$ ). In Croatia, payment facilities (weight of $22.7 \%$ ) were more important than quality (weight of $13.1 \%$ ). Furthermore, after-sales services (weight of $10.2 \%$ ) were the fourth and the manufacturer's reputation (weight of $7.9 \%$ ) was placed the fifth. In Slovenia, the price was in second place with a weight of $27.5 \%$, 


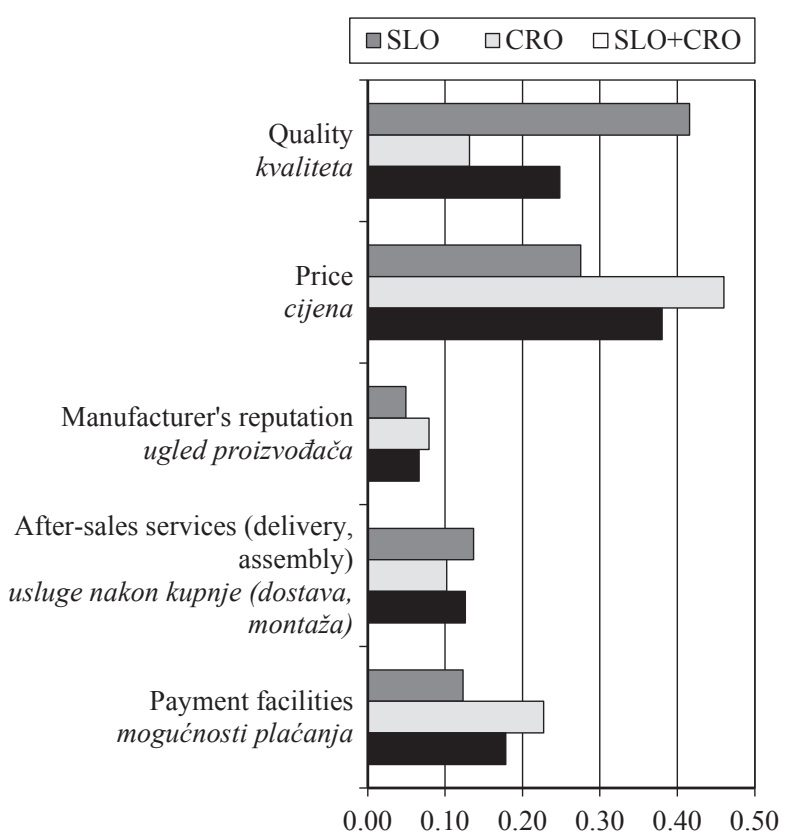

Figure 5 The most important criteria for the purchase of furniture

Slika 5. Najvažniji kriteriji kupca pri kupnji namještaja

after-sales services was in the third place with a weight of $13.7 \%$. Payment facilities took the fourth place with a weight of $12.3 \%$ and the manufacturer's reputation was in the fifth place with a weight of $4.9 \%$.

In Slovenia, the decision to purchase furniture was mostly made by both partners jointly (weight of $41.4 \%$ ), while in Croatia it was mostly made by women (weight of $57.2 \%$ ). Decisions made solely by women were in the second place in Slovenia (only a slightly lower weight of $40.0 \%$ ), decisions made by partners together with their children were in the third place (weight of $13.2 \%$ ), and decisions made solely by men were in the fourth place (weight of $5.4 \%$ ). In Croatia, decisions made by both partners were in the second place with a weight of $24.5 \%$, decisions made by both partners with their children were in the third place with a weight of $12.0 \%$ and decisions made solely by men were in the fourth place (weight of $6.4 \%$ ). The partners mostly made their decision together with their children when they were deciding to buy furniture for the children's bedroom.

\section{CONCLUSION \\ 5. ZAKLJUČAK}

In the study, the influences on joint decision making in the purchase of furniture in Slovenia and in Croatia were established. Additionally, the experts were asked about consumers' needs, desires and habits at every stage of their buying decision process. In this way, very interesting answers, which could be helpful to manufacturers and sellers of furniture seeking to satisfy the consumer's needs and effectively formulate their marketing mix, were acquired.

Furthermore, important differences between the buying behaviour of potential furniture buyers in Slovenia and in Croatia were identified. Consumers in

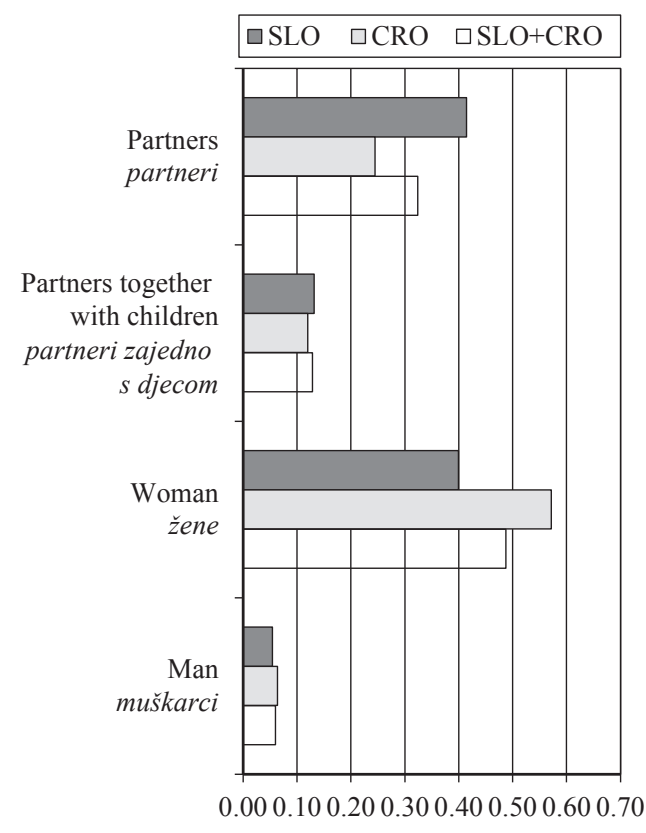

Figure 6 Decision makers on the purchase Slika 6. Donositelji odluke o kupnji

both countries were mostly stimulated to buy furniture due to low prices; slightly less due to the company's marketing activities and least of all due to the sales staff. The buying behaviour was also no different in the stage of the initial search for information on furniture. The Internet was, normally, found to be the first source of information and consumers would often also seek information in the furniture shops. However, they would less often seek information in the media and from their relatives, friends and acquaintances.

The results referred to the most important criteria for making a purchase show to be particularly interesting. In Slovenia, the quality of the product was found to be the most important; followed by price at the second place, after-sales services at the third place, and payment facilities at the fourth place. In Croatia, the criteria were arranged in a completely different order. The price was in the first place, followed by payment facilities, quality of products was in the third place and after-sales services in the fourth place.

In Slovenia, the decision to purchase furniture was mostly made together by both partners, while in Croatia it was mostly made by women. The partners often made a decision together with their children, especially when deciding about purchasing children's bedroom furniture. Additionally men would choose furniture by themselves very rarely.

The results of the study indicated that there were differences between the buying behaviour of potential furniture buyers in Slovenia and in Croatia. These findings could be helpful to furniture companies operating in these two target markets in the process of designing their marketing strategies.

Acknowledgment - Zahvala

Leon Oblak, Manja Kitek Kuzman and Petra Grošelj would like to acknowledge the Slovenian Re- 
search Agency for financial support in the framework of the programs P4-0015 and P4-0059.

\section{REFERENCES}

\section{LITERATURA}

1. Alonso, S.; Herrera-Viedma, E.; Chiclana, F.; Herrera, F., 2010: A web based consensus support system for group decision making problems and incomplete preferences. Information Sciences, 180 (23): 4477-4495. http://dx.doi.org/10.1016/j.ins.2010.08.005.

2. Altuzarra, A.; Moreno-Jiménez, J. M.; Salvador, M., 2007: A Bayesian priorization procedure for AHP-group decision making. European Journal of Operational Research, 182 (1): 367-382. http://dx.doi.org/10.1016/j.ejor.2006.07.025.

3. Esmaili, M.; Fazeli, S. F., 2015: Surveying of Importance of Green Marketing Compared Purchase Budget and Preferred Brand when Buying by AHP Method (Vol. 6).

4. Forman, E.; Peniwati, K., 1998: Aggregating individual judgments and priorities with the analytic hierarchy process. European Journal of Operational Research, 108 (1): 165-169. http://dx.doi.org/10.1016/s0377-2217(97)00244-0.

5. Grošelj, P.; Pezdevšek Malovrh, Š.; Zadnik Stirn, L., 2011: Methods based on data envelopment analysis for deriving group priorities in analytic hierarchy process. Central European Journal of Operations Research, 19 (3): 267-284 http://dx.doi.org/10.1007/s10100-011-0191-x.

6. Grošelj, P.; Zadnik Stirn, L.; Ayrilmis, N.; Kitek Kuzman, M., 2015: Comparison of some aggregation techniques using group analytic hierarchy process. Expert Systems with Applications, 42 (4): 2198-2204. http://dx.doi.org/10.1016/j.eswa.2014.09.060.

7. Kotler, P., 1994: Principles of marketing. New Jersey: Englewood Cliffs: Prentice-Hall.

8. Loučanova, E.; Parobek, J.; Paluš, H., 2014: Identification of Slovak customers' requirements for storage furniture based on the KANO model. Acta Facultatis Xylologiae, 56 (1): 109-117.

9. Motik, D.; Šegotić, K.; Jazbec, A., 2010: Application of AHP Model and Survey Results in Deciding on a Product Line in Furniture Industry. Drvna industrija, 61 (2): 83-87.
10. Oblak, L., 2012: Trženje lesnih izdelkov in storitev. Ljubljana: Biotehniška fakulteta, Oddelek za lesarstvo.

11. Ojurović, R.; Moro, M.; Šegotić, K.; Grladinović, T.; Oblak, L., 2013: Analysis of the Investment in Wood Processing and Furniture Manufacturing Entities by Key Factors of Competitiveness. Drvna industrija, 64 (2): 131-137. http://dx.doi.org/10.5552/drind.2013.1235.

12. Olšiakova, M; Loučanova, E; Paluš, H., 2016: Monitoring changes in consumer requirements for wood products in terms of consumer behavior. Acta Facultatis Xylologiae, 58 (1): 137-147.

13. Potočnik, V., 2002: Temelji trženja. Ljubljana: GV založba.

14. Saaty, T. L., 1980: The Analytic Hierarchy Process. New York: McGraw-Hill.

15. Saaty, T. L., 2006: Fundamentals of Decision Making and Priority Theory with the Analytic Hierarchy Process. Pittsburgh: RWS Publications.

16. Scholz, S. W.; Decker, R., 2007: Measuring the impact of wood species on consumer preferences for wooden furniture by means of the Analytic Hierarchy Process. Forest Products Journal, 57(3): 23-28.

17. Srđević, B.; Srđević, Z., 2013: Synthesis of individual best local priority vectors in AHP-group decision making. Applied Soft Computing, 13 (4): 2045-2056. http://dx.doi.org/10.1016/j.asoc.2012.11.010.

18. Stasiak Betlejewska, R., 2015: Construction product quality improvement with applying production problems analysis. Manufacturing technology, 15 (5): 756-761.

\section{Corresponding address:}

Assist. Prof. PETRA GROŠELJ, Ph.D.

University of Ljubljana

Biotechnical Faculty

Department for Forestry and Renewable Resources

Jamnikarjeva 101

SI-1000 Ljubljana, SLOVENIA

e-mail: petra.groselj@bf.uni-lj.si 